\title{
THE ROLE OF KNOWLEDGE MANAGEMENT IN BUSINESS PROCESS AND COMPETITIVENESS
}

\author{
Danica Rajin ${ }^{1 *}$, \\ Marijana Petrović \\ Tijana Radojević ${ }^{3}$, \\ Ričardas Butènas ${ }^{4}$ \\ ${ }^{1} F E F A$, Belgrade, Serbia \\ ${ }^{2}$ ICT College, Belgrade , \\ Serbia \\ ${ }^{3}$ Singidunum University, \\ Belgrade, Serbia \\ ${ }^{4}$ Kauno Kolegija, University of \\ Applied Sciences, Kaunas, \\ Lithuania
}

\begin{abstract}
:
The aim of this paper is to highlight the importance of shifting focus from material to intellectual resources. The globalization of markets, modern technology and corporate culture has created the need to assess the value of human capital and the efficient use of intellectual capital to create competitive advantage. Over time, intellectual resources have become an increasingly significant part of the total assets of companies. In the knowledge economy, human capital is a key factor in creating value and maintaining a competitive position, and in today's business environment, the need to measure the performance of intellectual capital has been created to determine its contribution.
\end{abstract}

\section{Keywords:}

knowledge economy, intellectual resources, intellectual capital

\section{INTRODUCTION}

The global economy has been unstoppably changing in recent years, with increasing importance to the knowledge economy and human capital, which has a strong impact on the development of business processes and the creation of competitive advantage in the market. Human capital emerges as a factor that significantly affects the quality of the organization itself, managing within it and creating the concept of value.

Companies that efficiently use knowledge, intellectual capital, or human potential as a consequence of expansion and development are considered to be knowledge-based companies. In such environment, innovation becomes a major driver of development. Namely, in the knowledge society, knowledge, innovation and quality become the bearers of competitive advantage. Learning organizations are emerging, and research and knowledge management are becoming a key source of competitiveness (Karaman, Aksentijević, Ježić, \& Đurić, 2008).

\section{THE IMPORTANCE OF HUMAN CAPITAL IN THE KNOWLEDGE ECONOMY}

In the global economy, the economy of scale no longer holds a significant place. At the moment when companies are beginning to base their business concept on a knowledge economy rather than a non-economical scale, there is a shift in focus from production volume to quality and higher value goods and services. The knowledge economy is based on specific skills and knowledge by which we are able

\author{
Correspondence: \\ Danica Rajin \\ e-mail: \\ drajin@fefa.edu.rs
}


to solve the identified problem. Specific knowledge management activities have a significant contribution to the business organization by directly influencing the focus on acquiring, storing and using problem-solving knowledge, dynamic learning, strategic planning and decision-making.

The quality of companies that possess such skills is multicultural, taking initiative, creative approach, communicative, conscience and responsibility, cooperative, understanding of technologies and environment. Innovation and creativity are recognized as managerial abilities to act strategically to generate alliances and encourage the business development and changes (Karaman Aksentijević, Ježić, \& Đurić, 2008). As stated by Drucker, the knowledge economy and the national knowledgebased economy are different from traditional companies in that the underlying resource becomes shareable information and the value of it grows through its use; location, that is, accommodation of the economy turns into immaterial - the market develops into virtual; laws, regulations and taxes are no longer of governmental importance; knowledge and information move where interest is greatest and barriers are least; prices become a matter of context and the same product or service may be differently charged each time; human potential becomes the core value of the knowledge economy (Drucker, 1992).

\section{KNOWLEDGE MANAGEMENT AND BUSINESS PROCESS MANAGEMENT}

Knowledge management is a relatively new, specialized management discipline whose task, from a theoretical and practical point of view, is to look at the problems of collecting, systematizing and using knowledge in contemporary organizations. The aim is to create and maintain a sufficient amount of concrete knowledge that can provide an adequate level of efficiency and effectiveness to organizations in maintaining or gaining a competitive advantage (Ćirić, I., Ćirić, Z., Sedlak, Eremić-Đođić \& Perin, 2014).

To understand knowledge, in terms of the successful implementation of a knowledge management program, we can start from the two most significant knowledge sharing (Lam, 2000): 1) knowledge from the point of view of epistemology: explicit and tacit (implicit - tacit) knowledge, 2) knowledge from the point of view of ontology: knowledge within an organization at the individual level, (individual knowledge) and at the organization level as a whole (collective or organizational knowledge).

In order to disseminate its expertise to potential loan beneficiaries, the World Bank has implemented a knowledge management system and created its own committee to address this issue. World Bank experts treat knowledge management as a process of systematically connecting people to people and people to knowledge and information in order to effectively act and create new knowledge. The objective of launching a knowledge management initiative is to improve the performance of the organization and individuals through the identification, acquisition, validation and transfer of knowledge.

Rudy Ruggles, one of the preeminent professional in the field of knowledge management has recognized the subsequent elements as a fundamental component of knowledge management:

- generation of new knowledge,

- having useful knowledge from external sources,

- using available knowledge to make decisions,

- embedding knowledge into processes, products and / or services,

- display knowledge in documents, databases and software,

- facilitating knowledge dissemination through organizational culture and initiative,

- transferring existing knowledge to other parts of the organization,

- measuring the value of knowledge and / or the impact of knowledge management.

Therefore, knowledge management is a systematically and organizationally defined process for gathering, organized communication of knowledge and skills among employees so that other employees can use it to improve the efficiency and productivity of their work (Alavi \& Leidner, 1999).

Adequate knowledge management in an organization should contribute to a situation where all relevant available knowledge will be successfully collected, organized and disseminated. What the knowledge management system will look like, or how it will be established and how it will function, depends solely on the specific situation in the organization (Ćirić, I., Ćirić, Z., Sedlak, Eremić-Đođić \& Perin, 2014).

Different opinions on the number and content of phases of the knowledge management model can be found in the literature. The process of knowledge management consists of five stages and includes (Sydanmaanlakka, 2002):
1) creation,
2) capture,
3) storing,
4) sharing and
5) application.

\section{KNOWLEDGE MANAGEMENT AND COMPETITIVE ADVANTAGE}

Companies are defined as combinations of 'tangible and intangible' resources, which are set up to pursue an economic activity to cover real or potential demand for products on the market and to generate net profits. 
The development of a "knowledge society" speaks of a major shift in terms of growth and contribution to enterprise value creation. A study conducted in the USA in 2001 pointed out that the book value of the company in 1978 represented $95 \%$ of the market value, and that in 2005 it accounted for only $25 \%$ of the market value (Ogrean \& Lucian, 2006). This fact, as a result of the aforementioned research, does not in any way mean that 'tangible' (material) resources are not relevant now, since there is no economy or company that can function without them. This, in fact, shows that the hierarchical relationship between resources has changed, that is, their relative importance for competitiveness in modern companies (Krstić, 2005). Namely, here we have in mind the advantages of the company acquired through timely access to information, efficient use of human and other intellectual resources, good reputation and image in contact with clients, bidders, as well as ethical behavior, transparent business operations (voluntary disclosure of information to external stakeholders), respect for rights employees, using processes that protect the environment and support environmental responsibility (Krstić \& Vukadinović, 2008).

Knowledge flow managemant contributes to enhancing value and competitiveness by improving its efficiency, connectivity and innovation (Tisen, Andriesen \& Lekan Depre, 2006).

In the business world, it is not only about knowing something about a business or having valuable information, but also about how to use a set of information in the specific business context and market situation in which the business is located.
Organizational knowledge can be identified and valorized through use or transfer only if it is incorporated into a coherent system, process, product, organizational culture. It is then processed information manifested in business routines and processes that enable company action (Krstić \& Vukadinović, 2008).

Today's business performance is mainly driven by the ability of a company to acquire, systematize and transmiss knowledge rapidly and more effectively than contestants are. (Myers, 1996).

Knowledge management was among the most represented management tools in companies according to research by the renowned consulting firm Bain \& Company (for example, in 2010 it was among the 25 and in 2006 among the 10 most used tools), but in the 2013, did not rank among the 25 management tools most used by companies (Rigby \& Bilodeau, 2015, 2013). If we look at the number of studies by renowned authors and research on this topic in general, the number seems to be declining. The question is to what extent and in what way this tool is used in practice today, and how the number of companies using it is changing, especially given the dramatic advancement of technologies and the abundance of various information available to all in the short term.

In the list of most common tools mentioned are some new tools, which are in an upward trend (Advanced Analytics, Agile Management, Balanced Scorecard and Benchmarking). An overview of the representation of management tools in companies globally is given in Figure 1.

Figure 1 - 25 most popular management tools
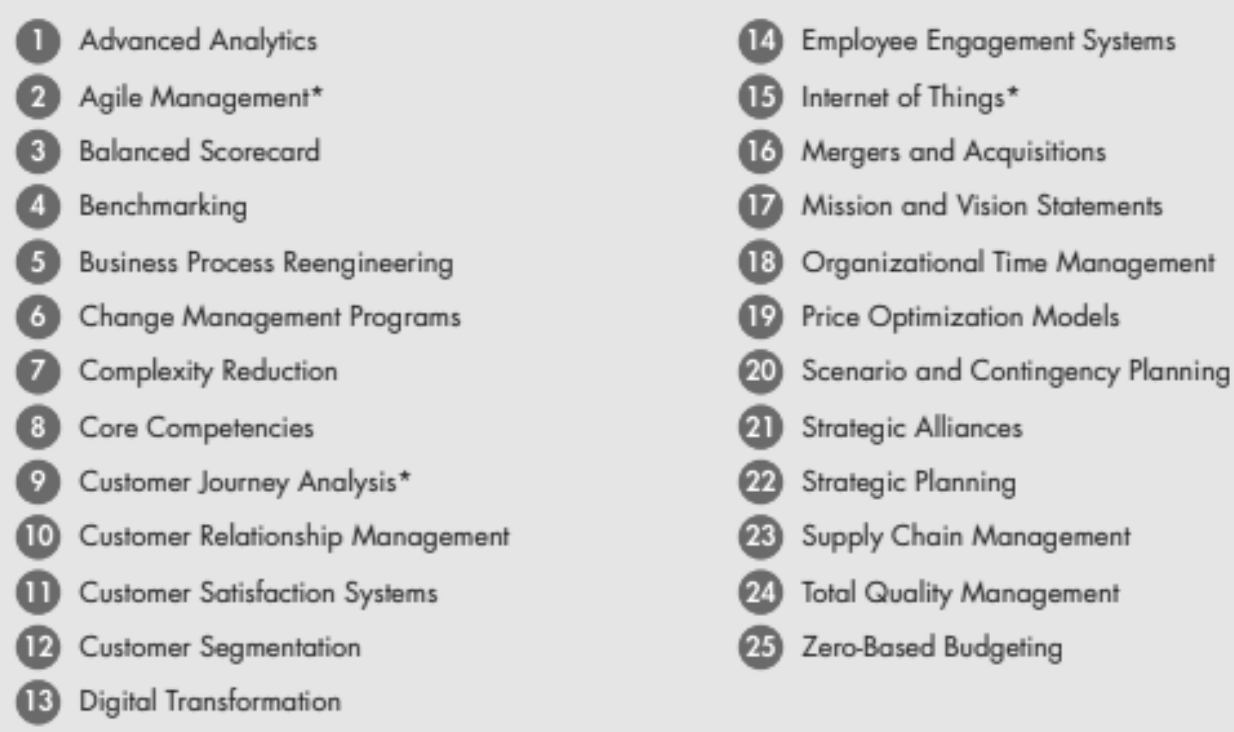

Source: Rigby, D. and Bilodeau, B. (2018) Management Tools \& Trends, Bain \& Company 
Although the representation of knowledge management as a tool is declining, the exchange of information and meaningful knowledge in organizations is stable. So, however, knowledge management is "good" but simply "going through certain stages": some companies have abandoned knowledge management programs because of the need to reduce costs, to later prove that they still need all that knowledge management involves - sharing, innovation, reuse, collaboration and learning; no matter what name they were called, these processes were needed by the companies and thus reintroduced. Garfield concludes that the field of knowledge management is therefore relatively stable, due to the constant need for processes and activities to be carried out within organizations. Is "the only thing that gives an organization a competitive edge - the only thing that can be sustainable - is what the organization realizes, the technique it uses what it knows, and the momentum with which something new can know."

Business cycles and changes in management theories influence the reputation of particular tools and tendencies. Figure 2 shows how the tools have varied over time.

Figure 2 - The top 10 tools have varied over
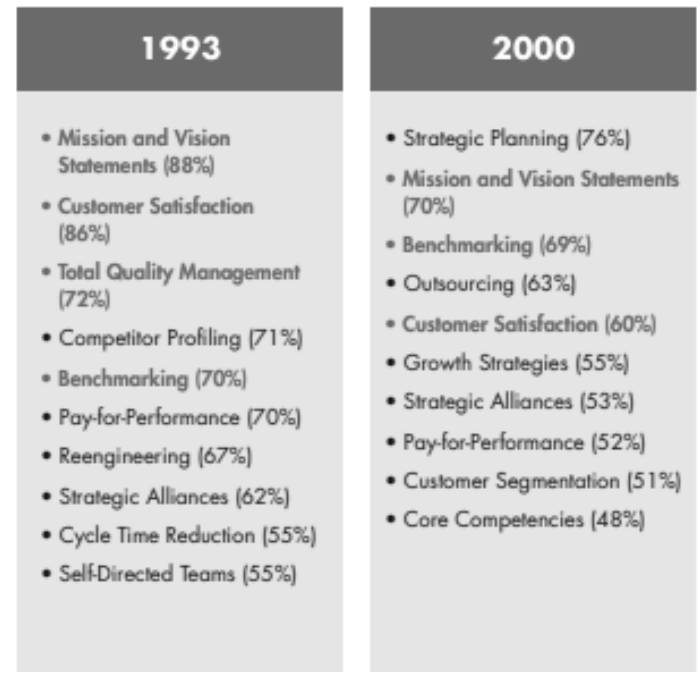

\begin{tabular}{l}
2014 \\
\hline - Customer Relationship \\
Management (46\%) \\
- Benchmarking (44\%) \\
- Employee Engagement \\
Surveys (44\%) \\
- Strategic Planning (44\%) \\
- Outsourcing (41\%) \\
- Balanced Scorecard [38\%) \\
- Mission and Vision \\
Statements (38\%) \\
- Supply Chain Manogement \\
(36\%) \\
- Change Management \\
Programs (34\%) \\
- Customer Segmentation (30\%)
\end{tabular}

\begin{tabular}{l}
2017 \\
\hline - Strategic Planning (48\%) \\
- Customer Relationship \\
Management (48\%) \\
- Benchmarking (46\%) \\
- Advanced Analylies (42\%) \\
- Supply Chain Manogement \\
(40\%) \\
- Customer Salisfoction (38\%) \\
- Change Management \\
Programs (34\%) \\
- Total Quality Management \\
(34\%) \\
- Digital Transformation (32\%) \\
- Mission and Vision Statements \\
(32\%)
\end{tabular}

Source: Rigby, D. and Bilodeau, B. (2018) Management Tools \& Trends, Bain \& Company

At the top of the list for 2017's most popular tool management is Strategic Planning, the mechanism of determining what a business should become and how paraphrase it can realize that intention.

Strategic planning is at the forefront of global uses (Figure 3), at least when it comes to the opportunities and threats posed by digital technology and the development of the digital economy. As companies increasingly turn to the so-called fourth industrial revolution, expecting to grow and thrive in a rapidly changing business environment, understanding how to be valuable to customers just becomes even more vital. Therefore, it is a bit of a surprise for customer relations management, which focuses on crucial matter of understandig customers shifting desires, ranks and responding to their aspiration.

Figure 3 - The view on management trends 
Overall, Bain \& Company's $15^{\text {th }}$ Management Tools \& Trends survey showed executives confident and upbeat - 74\% said their current financial performance is strong, and $55 \%$ believe economic conditions are improving in their industry (Figure 4), with pharma and biotech, construction and real estate, and financial services being the most optimistic sectors.

Figure 4 - The view on management trends

\begin{tabular}{|ccc|}
\hline & Agree & Disagree \\
\hline Our ability to adapt to change is a significant competitive advantage & $75 \%$ & $13 \%$ \\
\hline Innovation is more important than cost reduction for long-term success & $74 \%$ & $9 \%$ \\
\hline Our current financial performance is strong & $74 \%$ & $10 \%$ \\
\hline Over the next three years, our IT spending must increase as a percent of sales & $16 \%$ \\
\hline Customers are less loyal to brands than they used to be & $64 \%$ & $19 \%$ \\
\hline Excessive complexity is raising our costs and hindering our growth & $62 \%$ & $18 \%$ \\
\hline Sustainability initiatives are improving our growth and profitability & $60 \%$ & $13 \%$ \\
\hline Our management actions favor long-term results over short-term earnings & $59 \%$ & $22 \%$ \\
\hline Effective mergers and acquisitions will be critical to success in our industry & $58 \%$ & $22 \%$ \\
\hline The principles and passions of our founders still dominate our operating practices today & $57 \%$ & $22 \%$ \\
\hline I am very concerned about the impact that a cyber attack could have on our business & $57 \%$ & $23 \%$ \\
\hline It feels like economic conditions are improving in our industry & $55 \%$ & $24 \%$ \\
\hline Increased price transparency has had a major impact on our pricing strategy & $55 \%$ & $14 \%$ \\
\hline Over the next three years, we will focus more on revenue growth than cost reduction & $54 \%$ & $27 \%$ \\
\hline Advanced analytics are transforming our marketing strategy & $52 \%$ & $14 \%$ \\
\hline We use experimentation and testing techniques proficiently & $52 \%$ & $24 \%$ \\
\hline Insufficient consumer insight is hurting our performance & $48 \%$ & \\
\hline Our current information systems are constraining profitable growth & $46 \%$ & $29 \%$ \\
\hline Our top management is unwilling to take greater risks for higher returns & $42 \%$ & $32 \%$ \\
\hline We don't have the technology capabilities required to be a leader in our industry & $39 \%$ & $39 \%$ \\
\hline S & $29 \%$ & $56 \%$ \\
\hline
\end{tabular}

Source: Rigby, D. and Bilodeau, B. (2018) Management Tools \& Trends, Bain \& Company

\section{THE KNOWLEDGE ECONOMIC INDEX}

Research that tracks the conditionality of the development of the knowledge factor and the bases of particular knowledge economies are of particular use. Ranking of the list of countries in transition according to The Knowledge Economic Index (KEI) and Knowledge Index is given in
Table 1; while Table 2 gives a comparison of the leading countries according to the competitiveness rankings with respect to their innovation rankings, while Table 3 gives an overview of the realized GDP per capita and KE index for the group of leading countries and a number of developing countries.

Table 1 - Ranking of leading transition countries by KEI and KI indexes

\begin{tabular}{|c|c|c|c|c|c|c|c|}
\hline Rang & Country & KEI & KI & Economic Incetive Regime & Innovation & Education & ICT \\
\hline- & Sweden* & 9.43 & 9.38 & 9.58 & 9.74 & 8.92 & 9.49 \\
\hline 1 & Estonia & 8.40 & 8.26 & 8.81 & 7.75 & 8.60 & 8.44 \\
\hline 2 & Czech Republic & 8.14 & 8.00 & 8.53 & 7.90 & 8.15 & 7.96 \\
\hline 3 & Hungary & 8.02 & 7.93 & 8.28 & 8.15 & 8.42 & 7.23 \\
\hline 4 & Slovenia & 8.01 & 7.91 & 8.31 & 8.50 & 7.42 & 7.80 \\
\hline 5 & Lithuania & 7.80 & 7.68 & 8.15 & 6.82 & 8.64 & 7.59 \\
\hline 6 & Slovakia & 7.64 & 7.46 & 8.17 & 7.30 & 7.42 & 7.68 \\
\hline 7 & Latvia & 7.41 & 7.15 & 8.21 & 6.56 & 7.73 & 7.16 \\
\hline 8 & Poland & 7.41 & 7.20 & 8.01 & 7.16 & 7.76 & 6.70 \\
\hline 9 & Croatia & 7.29 & 7.27 & 7.35 & 7.66 & 6.15 & 8.00 \\
\hline 10 & Romania & 6.82 & 6.63 & 7.39 & 6.14 & 7.55 & 6.19 \\
\hline 11 & Bulgaria & 6.80 & 6.61 & 7.35 & 6.94 & 6.25 & 6.66 \\
\hline 12 & Serbia & 6.02 & 6.61 & 4.23 & 6.47 & 5.98 & 7.39 \\
\hline 13 & Russia & 5.78 & 6.96 & 2.23 & 6.93 & 6.79 & 7.16 \\
\hline 14 & Ukraine & 5.73 & 6.33 & 3.95 & 5.76 & 8.26 & 4.96 \\
\hline 15 & Macedonia & 5.65 & 5.73 & 4.99 & 5.15 & 6.74 & \\
\hline
\end{tabular}

Source: The World Bank; KEI and KI Indexes (KAM 2012) 
Table 2 - Comparison of Competitiveness Ranks (GCI) and Innovation

\begin{tabular}{ccccc}
\hline \multirow{2}{*}{ Country } & \multicolumn{2}{c}{ GCI 12/13 } & \multicolumn{2}{c}{ Innovation } \\
\cline { 2 - 5 } & Rank & Result & Rank & Result \\
\hline Switzerland & 1 & 5.67 & 13.72 & 5.14 \\
\hline Singapore & 2 & 5.61 & 2 & 5.65 \\
\hline Finland & 3 & 5.54 & 4 & 5.59 \\
\hline Germany & 4 & 5.51 & 6 & 5.43 \\
\hline USA & 5 & 5.48 & 5.46 \\
\hline Sweden & 6 & 5.48 & 19 & 4.83 \\
\hline Hong Kong & 7 & 5.47 & 7 & 5.36 \\
\hline Netherlands & 8 & 5.52 & 3 & 5.62 \\
\hline Japan & 9 & 5.40 & 10 & 5.15 \\
\hline UK & 10 & 5.37 & 5 & \\
\hline
\end{tabular}

Source: The World Bank; KEI and KI Indexes (KAM 2012)

Table 3 - Comparison of GDP levels per capita and KEI

\begin{tabular}{|c|c|c|}
\hline Country & GDP per capita USA \$ & KE index \\
\hline Luxembourg & 107.206 & 8.37 \\
\hline Norway & 99.462 & 9.11 \\
\hline Switzerland & 79.033 & 8,87 \\
\hline Denmark & 56.202 & 9.16 \\
\hline Sweden & 55.158 & 9,43 \\
\hline Canada & 52.232 & 8.92 \\
\hline USA & 49.922 & 8.77 \\
\hline Japan & 46.736 & 8.28 \\
\hline Finland & 46.098 & 9.33 \\
\hline Belgium & 43.686 & 8.71 \\
\hline Germany & 41.513 & 8.90 \\
\hline France & 41.141 & 8.21 \\
\hline UK & 38.589 & 8.76 \\
\hline Slovenia & 22.193 & 8.01 \\
\hline Czech rep. & 18.579 & 8.14 \\
\hline Slovak rep. & 16.899 & 7.64 \\
\hline Estonia & 16.320 & 8.40 \\
\hline Russia & 14.247 & 5.78 \\
\hline Croatia & 12.972 & 7.29 \\
\hline Hungary & 12.736 & 8.02 \\
\hline Poland & 12.538 & 7.41 \\
\hline Turkey & 10.609 & 5.16 \\
\hline Bulgaria & 7.033 & 6.80 \\
\hline Montenegro & 6.882 & - \\
\hline Serbia & 4.943 & 6.02 \\
\hline Macedonia & 4.683 & 5.65 \\
\hline $\mathrm{BiH}$ & 4.461 & 5.12 \\
\hline Albania & 3.913 & 4.53 \\
\hline
\end{tabular}

Source: The World Bank; KEI and KI Indexes (KAM 2012) 


\section{CONCLUSION}

Knowledge today is the most important resource that ensures the competitive advantage of every organization. Therefore, adequate management of this resource is necessary. Knowledge management has a significant impact on business process management in an organization and has a positive impact on business decision making in business systems. Knowledge management is a business concept that aims at organizational knowledge. Successful knowledge management in an organization is not just about storing knowledge that will be accessible to all employees, but creating knowledge that enhances the value of the organization through the integration of knowledge of people, processes and technology. Knowledge management in companies leads to improved communication and cooperation between employees, which creates mutual trust that influences the creation of a positive business climate in modern organizations.

\section{LITERATURE}

1. Alavi, M. \& Leidner, D. (1999). Knowledge Management Systems: Issues, Challenges and Benefits, Communications of the Association for Information Systems: Vol. 1, Article 7. Retrieved from: http://aisel.aisnet.org/cais/voll/ iss $1 / 7$ (15.09.2019)

2. Ćirić, I., Ćirić, Z., Sedlak, O., Eremić-Đođić, J., Perin, J. (2014) Upravljanje znanjem u ostvarivanju konkurentske prednosti preduzeća, Infoteh - Jahorina, Vol. 13, March 2014., Retrieved from https://infoteh.etf.ues.rs.ba/ zbornik/2014/radovi/RSS-3/RSS-3-1.pdf (15.09.2019) Darrell, R. \& Bilodeau, B. (2013), Management Tools \& Trends 2013, London: Bain \& Company

3. Darrell, R. \& Bilodeau, B. (2015) Management Tools \& Trends 2015, London: Bain \& Company

4. Drucker, P.F. (1992) Nova zbilja. Zagreb: Novi liber

5. Karaman Aksentijević, N., Ježić, Z. \& Đurić, K. (2008) Upravljanje ljudskim potencijalima kao pretpostavka inovativnosti i uspješnosti poslovanja, Informatologia, Vol. 41, no.1, pp. 46-50

6. Krstić, B. \& Vukadinović, B. (2008) Upravljanje znanjem kao izvor održive konkurentnosti preduzeća, Ekonomske teme, Vol. 3, pp. 85-98 Retrieved from http://xn----itbaba0aapeekb4br.xn--90a3ac/pdf/et20083_06.pdf(15.09.2019)

7. Krstić, B. (2005) Merenje performansi upotrebe resursa u funkciji upravljanja preduzećem, Ekonomski fakultet, Niš, pp.13

8. Lam, A. (2000) Tacit Knowledge, Organizational Learning and Societal Institutions: An Integrated Framework, Organization Studies, University of Kent, Canterbury, pp. 489. Retrieved from https://journals.sagepub.com/ doi/10.1177/0170840600213001 (15.09.2019)
9. Myers, P.S. (1996) Knowledge Management and Organizational Design, Butterworth-Heinemann Publishing

10. Ogrean, C., \& Lucian, B. (2006) Knowledge Management - a source of sustainable competitiveness in the knowledge based economy, MPRA Paper No. 1688, August 2006, page 6

11. Sydanmaanlakka, P. (2002). An Intelligent Organization: Integrating Performance, Competence and Knowledge Management, Capstone Publishing Oxford

12. Tisen, R., Andriesen, D. \& Lekan Depre, F. (2006) Dividenda znanja - stvaranje kompanija sa visokim učinkom kroz upravljanje znanjem kao vrednošću, Novi Sad: Adižes 